\title{
REVIEW
}

\section{Size dependence of growth and photosynthesis in diatoms: a synthesis}

\author{
Richard J. Geider ${ }^{1}{ }^{*}$, Trevor Platt $^{2}$ \& John A. Raven ${ }^{1}$ \\ ${ }^{1}$ Department of Biological Sciences, The University of Dundee, Dundee, Scotland, U.K. \\ ${ }^{2}$ Marine Ecology Laboratory, Bedford Institute of Oceanography, P.O.B. 1006, Dartmouth, Nova Scotia B2Y 4A2, Canada
}

\begin{abstract}
The dependence of growth and photosythesis on cell size in diatoms is evaluated in terms of an energy-balance model of microalgal physiology. Based on a review of available observations it appears that cell size can account for much of the interspecific variability in maximum growth rate $\left(\mu_{m}\right)$ and in optical absorption cross-section $\left(a_{c h l}\right)$. Both $\mu_{m}$ and $a_{c h l}$ decrease with increases in cell size. Cell size does not appear to influence the chlorophyll a:carbon ratio, the quantum efficiency of photosynthesis nor the photon flux density (PFD) at which growth rate is light-saturated. Available observations do not allow an evaluation of the size dependence of maintenance metabolic rates or the PFD at which light compensation of growth occurs. This analysis confirms the competitive advantage of small cell size of microalgae under nutrient-sufficient conditions at both light-saturating and light-limiting growth rates to the extent that small-celled diatoms have enhanced catalytic efficiencies of growth and light absorption.
\end{abstract}

\section{INTRODUCTION}

The unicellular algae range in size from cells of less than $1 \mu \mathrm{m}$ diameter for some picoplanktonic chlorophytes and prasinophytes to cells of over $1 \mathrm{~mm}$ in length in some diatoms, dinoflagellates and chlorophytes (Sournia 1981). A number of selective pressures, some relating to the rates of energy use and nutrient transport by the cell, and hence to growth rate, and others relating to loss rates such as grazing and sinking, will be affected by cell size (Cavalier-Smith 1982).

Rates of metabolic processes in both multicellular and unicellular organisms generally have a size dependence that can be described by an allometric relation:

$$
\text { rate }=\mathrm{a} \mathrm{W}^{\mathrm{b}}
$$

where 'rate' $=$ the specific rate of some metabolic process (units of inverse time); $\mathrm{W}=\mathrm{a}$ measure of

\footnotetext{
- Current address: Department of Plant Biology, The University of Birmingham, P.O. Box 363, Birmingham B15 2TT England, U.K.
}

(C) Inter-Research/Printed in F. R. Germany organism mass; $a$ and $b=$ coefficients (Peters 1983). When metabolic rates are expressed in units of inverse time and size is expressed in units of mass the exponent of the allometric relation generally takes values from -0.33 to -0.25 (Fenchel 1974, Banse 1982a, Peters 1983): in other words specific metabolic rates decrease with increasing size.

A reduction in cell division rate with increased size is documented in microalgae (Banse 1976, Blasco et al. 1982), although the magnitude of the exponent has been the subject of some discussion (Chan 1978, Banse 1982a). In particular, it appears that size dependence of metabolic rates only become statistically significant when organisms from a large range of sizes are considered and when care is taken to discriminate among metabolic and/or taxonomic types. For example, the growth rates of diatoms and dinoflagellates of equal size can differ by a factor of 3 and other groups appear to have intermediate growth rates (Banse 1982a). In addition to systematic variations in growth rates, different classes of microalgae are characterized by differences in chemical composition (Chan 1978, Hitchcock 1982).

Compounding the difficulty of making interspecific comparisons of growth and metabolic rates in microal- 
gae are the known phenotypic responses of chemical composition and metabolic rates to variations in environmental conditions. Phenotypic variations in intracellular pigment content, activities of various enzymes, photosynthesis and respiration rates, cell volume, and chemical composition occur in response to nutrient availability (Goldman 1980) photon flux density (Falkowski 1980) and temperature (Li 1980). This phenotypic variability should be taken into consideration when examining the size dependence of microalgal physiology.

A mechanistic model based on the flux of mass and energy through the algal cell can account for much of the phenotypic variability in microalgal physiology (Shuter 1979, Laws et al. 1983). Under nutrient-sufficient conditions this model reduces to an energy budget for microalgal growth (Laws et al. 1983, Geider 1984). Our investigation considers the size dependence of the variables in an energy budget for microalgal growth, but is limited primarily to the Bacillariophyceae because this is the class for which size effects on growth, photosynthesis and chemical composition are best documented. Information from other classes of microalgae and the cyanobacteria will be used where expedient or where useful comparisons can be drawn. Use of an energy budget facilitates the comparison of growth and metabolic rates with chemical composition and provides a means for organizing information from a number of different investigations into a unified treatment.

\section{THEORETICAL MODEL OF MICROALGAL GROWTH}

Recent theoretical models of microalgal growth (Shuter 1979, Kiefer \& Mitchell 1983) have been based implicitly or explicitly on an account of the conservation of energy within a growing cell. Accounting for this energy budget is also an essential part of the empirical model of microalgal growth developed by Eppley \& Sloan (1966) and Bannister's (1979) treatment of nutrient-saturated growth in Chlorella. Neglecting excretion, the energy balance simply states that the gross photosynthesis rate is equal to the sum of the growth and respiration rates (i.e. photosynthesis = growth + respiration). This section considers the parameterization of photosynthesis, growth and respiration rates in an energy budget equation. Later sections will consider the effects of cell size on the numerical values of the variables in the energy-balance equation. Symbols used in this paper are summarized in Table 1.

Following Kiefer \& Mitchell (1983) one can express the photosynthesis rate as the product of a quantum efficiency of photosynthesis, an absorption cross-sec-
Table 1. Summary of notation. All symbols are defined on first appearance in the text; commonly occurring symbols are summarized here for convenience

\begin{tabular}{|c|c|}
\hline Symbol & Definition \\
\hline I & Photon flux denity \\
\hline $\mathrm{P}^{c}$ & Carbon-specific photosynthesis rate \\
\hline $\mathrm{P}_{\mathrm{m}}^{\mathrm{c}}$ & $\begin{array}{l}\text { Carbon-specific, light-saturated photosyn- } \\
\text { thesis rate }\end{array}$ \\
\hline $\mathrm{P}_{m}^{\mathrm{chl}}$ & $\begin{array}{l}\text { Chlorophyll a-specific, light-saturated photo- } \\
\text { synthesis rate }\end{array}$ \\
\hline z & $\begin{array}{l}\text { Dimensional constant equal to the atomic } \\
\text { mass of carbon }\end{array}$ \\
\hline$a_{c h l}$ & $\begin{array}{l}\text { Chlorophyll } a \text {-specific, light absorption coeffi- } \\
\text { cient }\end{array}$ \\
\hline $\mathrm{r}$ & Respiration rate \\
\hline$r_{m}$ & Maintenance metabolic rate \\
\hline$\alpha$ & $\begin{array}{l}\text { Initial slope of the photosynthesis-light re- } \\
\text { sponse curve }\end{array}$ \\
\hline$\varphi_{p}$ & $\begin{array}{l}\text { Photon (quantum) efficiency of gross photo- } \\
\text { synthesis }\end{array}$ \\
\hline$\varphi_{\mathrm{m}}$ & Maximum photon efficiency of photosynthesis \\
\hline$\theta$ & Chlorophyll a: carbon ratio \\
\hline$\mu$ & Growth rate \\
\hline$\mu_{\mathrm{m}}$ & $\begin{array}{l}\text { Maximum, species-specific growth rate } \\
\text { Energy cost of synthesis }\end{array}$ \\
\hline
\end{tabular}

tion expressed on a unit chlorophyll a basis, the cell chlorophyll a:carbon ratio and the photon flux density (PFD):

$$
\mathrm{P}^{c}(\mathrm{I})=Z \varphi_{\mathrm{p}} \mathrm{a}_{\mathrm{chl}} \theta \mathrm{I}
$$

where $\mathrm{P}^{\mathrm{c}}(\mathrm{I})=$ gross photosynthesis rate in units $\mathrm{s}^{-1} ; \mathrm{Z}$ $=\mathrm{a}$ dimensional constant equal to the atomic mass of carbon $(0.012 \mathrm{mgC} / \mu \mathrm{mol} \mathrm{C}) ; \varphi_{\mathrm{p}}=$ the quantum efficiency of photosynthesis ( $\mathrm{mol} \mathrm{C/mol} \mathrm{photons);} \mathrm{a}_{\mathrm{chl}}=$ the chlorophyll a-specific absorption cross-section $\left(\mathrm{m}^{2} /\right.$ mg chla); $\theta=$ the chlorophyll a:carbon ratio ( $m g$ chlal mgC); $I=$ the photon flux density ( $\mu$ mol photons $\mathrm{m}^{-2}$ $s^{-1}$.

This treatment differs from Shuter (1979) by considering the quantum efficiency and absorption crosssection separately whereas Shuter considers only the product of the 2 terms. Also, unlike Shuter, we do not consider the product $\left(\varphi_{p} a_{c h l}\right)$ to be constant.

Kiefer \& Mitchell (1983) considered the quantum efficiency of photosynthesis to decrease with increases in PFD:

$$
\varphi_{\mathrm{p}}=\varphi_{\mathrm{m}} K /(\mathrm{K}+\mathrm{I})
$$

where $K=$ a coefficient that characterizes the decrease of efficiency of photosynthesis with increases in PFD; $\varphi_{m}=$ the maximum quantum efficiency of photosynthesis. It can be shown that the PFD dependence of $\varphi_{p}$ implied by Eq. $2 \& 3$ implies a rectangular hyperbolic 
expression for the photosynthesis-light curve (Laws et al. 1985) which is but one possible 2-parameter equation for the PI curve. For PFDs which are not photoinhibitory the light dependence of gross photosynthesis can be described using several 2-parameter equations (Jassby \& Platt 1976). In this discussion we assume that the rate of photosynthesis can be described using an exponential function (Eq. 4), although other saturating functions, such as the rectangular hyperbola, can be employed.

$$
\mathrm{P}^{c h l}(\mathrm{I})=\mathrm{P}_{\mathrm{m}}^{\mathrm{chl}}\left[1-\exp \left(\alpha \mathrm{I} / \mathrm{P}_{\mathrm{m}}^{\mathrm{chl}}\right)\right]
$$

where $\mathrm{P}^{\mathrm{chl}}(\mathrm{I})=$ the chlorophyll a-specific gross photosynthesis rate $\left(\mathrm{mg} \mathrm{C}[\mathrm{mg} \mathrm{chla}]^{-1} \mathrm{~s}^{-1}\right)$; $\mathrm{P}_{\mathrm{m}}^{\mathrm{chl}}=$ the light saturated, chlorophyll a-specific gross photosynthetic rate; $\alpha=$ the initial slope of the PI curve with units of ( $\mathrm{m}^{2} / \mathrm{mg}$ chla) (mg C/umol photon).

The initial slope can be expressed as the product of the absorption cross-section, the maximum quantum efficiency of photosynthesis and a dimensional constant (Eq. 5), and the chlorophyll a-specific light saturated photosynthesis rate can be expressed as a function of the chlorophyll a:carbon ratio and a carbonspecific, light-saturated photosynthesis rate (Eq. 6):

$$
\begin{gathered}
\alpha=\varphi_{m} a_{c h l} Z \\
P_{m}^{c h l}=P_{m}^{c} / \theta
\end{gathered}
$$

where $\mathrm{P}_{m}^{c}=$ the carbon specific, light-saturated photosynthesis rate $\left(\mathrm{s}^{-1}\right)$; the other terms are as defined above.

The actual quantum efficiency of photosynthesis $\left(\varphi_{p}\right)$, as distinguished from the maximum quantum efficiency $\left(\varphi_{m}\right)$, can be expressed in terms of the parameters of the PI curve as follows

$$
\varphi_{\mathrm{p}}=\varphi_{\mathrm{m}}\left[\mathrm{P}^{\mathrm{chl}}(\mathrm{I}) / \alpha \mathrm{I}\right]
$$

Substituting Eq. 4 into 5 followed by 5 and 6 into 7 yields

$$
\varphi_{\mathrm{p}}=\mathrm{P}_{\mathrm{m}}^{\mathrm{c}}\left[1-\exp \left(\mathrm{Z} \varphi_{\mathrm{m}} \vartheta \mathrm{I} / \mathrm{P}_{\mathrm{m}}^{\mathrm{c}}\right)\right]
$$

Eq. 8 illustrates that the quantum efficiency of photosynthesis is not independent of the other variables in the PI curve (i.e. $\varphi_{m}, a_{c h l}, \theta, P_{m}^{c}$ ). In this respect our treatment differs from Kiefer \& Mitchell (1983) who consider $\varphi_{p}$ to depend on PFD through Eq. 3 and the parameter K. It is not clear from Kiefer \& Mitchell's (1983) analysis to what extent the decline in $\varphi_{\mathrm{p}}$ is due to a decrease in the initial slope of the PI curve or a decrease in photosynthesis rate due to light saturation.

Substituting the expression for the quantum effi- ciency of photosynthesis ( $\varphi_{p}$ as given in Eq. 8) into Eq. 2 yields

$$
\mathrm{P}^{c}(\mathrm{I})=\mathrm{P}_{\mathrm{m}}^{c}\left[1-\exp \left(\mathrm{Z} \varphi_{\mathrm{m}} \mathrm{a}_{\mathrm{chl}} \theta \mathrm{I} / \mathrm{P}_{\mathrm{m}}^{c}\right)\right]
$$

Eq. 9 and Eq. $2 \& 3$ are alternative expressions of the photosynthesis-light curve written in terms of the same parameters. Our treatment differs from Kiefer \& Mitchell (1983) in that Eq. 9 is a PI curve based on an exponential function whereas Eq. 2 \& 3 yield a PI curve based on the rectangular hyperbola. This in itself is a trivial difference related only to the mathematical function chosen to describe the shape of the PI curve. In Eq. 9, however, the entire PI curve is explicitly considered, whereas Eq. 2 \& 3 refer only to the rate of photosynthesis at a single PFD (i.e. the light level to which the cells are acclimated). The consideration of the entire PI curve results from the introduction of an additional and potentially useful photoadaptive variable (i.e. the light-saturated photosynthesis rate $\mathrm{P}_{\mathrm{m}}^{\mathrm{c}}$ ).

The other components of the energy budget for growth are the growth rate and the respiration rate. Following Shuter (1979) the respiration rate can be expressed as the sum of a maintenance metabolic rate and a growth-rate-dependent cost of cell synthesis, where again the rates are expressed in units of inverse time:

$$
r=r_{m}+\mu \xi
$$

where $\mathrm{r}=$ the respiration rate $\left(\mathrm{s}^{-1}\right) ; \mathrm{r}_{\mathrm{m}}=$ the maintenance metabolic requirement $\left(\mathrm{s}^{-1}\right) ; \mu=$ the growth rate $\left(\mathrm{s}^{-1}\right) ; \xi=$ the cost of synthesis (dimensionless).

The energy balance equation (photosynthesis = growth + respiration] can be written as follows:

$\mu(1+\xi)+I_{m}=P_{m}^{c}\left[1-\exp \left(Z \varphi_{m} a_{c h l} \theta I / P_{m}^{c}\right)\right]$

This model contains 1 independent environmental variable (I), and 7 dependent metabolic variables $\left(\mu, r_{m}, \xi\right.$, $\theta, \varphi_{\mathrm{m}}, \mathrm{a}_{\mathrm{chl}}$, and $\mathrm{P}_{\mathrm{m}}^{\mathrm{c}}$ ). We will refer to a variable as photoadaptive if its numerical value depends on PFD at which a microalga is growing.

The remainder of this paper considers the size dependence of microalgal metabolism in terms of the size dependence of the variables in the energy balance equation (Eq. 11). In this way information derived from a number of independent sources can be combined in a unified treatment of nutrient-sufficient microalgal metabolism.

\section{Maintenance metabolic rate $\left(r_{m}\right)$}

Processes which contribute to the maintenance metabolic costs include the turnover of the macro- 
molecular components of the plant cell and the maintenance of solute gradients between the cell and its environment (Raven 1976). The numerical value of the maintenance metabolic rate is usually considered to be independent of growth rate, but dependent on cell mass in bacteria and microalgae (Pirt 1965, Shuter 1979). The flux of solutes into or out of the cell should be proportional to cell surface area (Raven 1984a), and the rnass-specific cost of solute regulation should thus depend on the relation (Strathman 1967) between cell mass and cell volume. In contrast, the mass-specific maintenance cost (units of inverse time) for turnover of the macromolecular components of a cell should be independent of cell mass.

The numerical value of maintenance metabolic rate has been estimated from extrapolation of growth-ratedependent, dark respiration rates to zero growth (Laws et al. 1983, 1985), measurement of respiration rates after prolonged (several hour) incubations in darkness (French et al. 1934), or extrapolation of light-limited growth rates to zero growth (Van Liere \& Mur 1979). The limited number of observations preclude an empirical evaluation of the size dependence of $\mathrm{r}_{\mathrm{m}}$. We will use a constant value of $r_{\mathrm{m}}=0.7 \times 10^{-7} \mathrm{~s}^{-1}$ based on observations for marine microalgae (Laws \& Caperon 1976, Laws \& Wong 1978, Verity 1982). Estimates of $r_{m}$ for freshwater chlorophytes are somewhat larger (2 to $3.5 \times 10^{-7} \mathrm{~s}^{-1}$ ) based on the summary in Van Liere \& Mur (1979).

\section{Energy cost of synthesis ( $\xi)$}

The cost of synthesis accounts for the energy required for production of the complex macromolecules which make up the algal cell from simple carbohydrates (considered to be the initial products of photosynthesis) and inorganic nutrients. The cost of synthesis can be calculated from a consideration of the biochemical pathways leading to the synthesis of the major classes of macromolecules (protein, lipid, nucleic acids, carbohydrates) including the costs of assimilating inorganic ions (Penning de Vries et al. 1974, Raven 1976). As a consequence $\xi$ should vary with the form of the inorganic nutrients used for growth, especially with respect to the form of nitrogen supplied, and the chemical composition of the microalgae as reflected in the carbon:nitrogen ratio (for example see Shuter [1979]).

Direct estimates of $\xi$ have been based on the slopes of linear regressions of mass-specific dark respiration rate $\left(r_{d}\right)$ on growth rate (Laws et al. 1983). The slopes of these regressions (Laws \& Caperon 1976, Laws \& Wong 1978, Verity 1982, Laws et al. 1983) generally yield values of $\xi$ which are less than those derived from theoretical analyses described in the preceeding paragraph, and $r_{d}$ is independent of growth rate in several species examined (Falkowski et al. 1985, Geider et al. 1985). It appears that the $r_{d}$ is not a good indicator of metabolic processes occuring in the light (Raven 1976), and that we must rely on theoretical calculations (Penning de Vries et al. 1974, Raven 1976) for an evaluation of the energy costs of synthesis. For this discussion we will consider $\xi$ to have a fixed value that can, however, depend on the inorganic nitrogen source.

\section{Maximum quantum efficiency of photosynthesis $\left(\varphi_{\mathrm{m}}\right)$}

The maximum quantum efficiency of photosynthesis $\left(\varphi_{m}\right)$ is constrained by the $\mathrm{Z}$ scheme of photosynthesis to a value of less than $0.125 \mathrm{~mol} \mathrm{O}_{2} / \mathrm{mol}$ photons. There is a substantial energetic inefficiency even in this maximum attainable value, because of the requirement that the transformation of energy from photons to chemical bonds proceeds unidirectionally and at a finite rate (Raven 1984a). In practice, somewhat lower efficiencies would be expected due to energy losses from back reactions at the reaction centers, inefficiencies of energy transfer in antennae pigments and multiple hits on closed reaction centers (Myers 1980). A commonly accepted value for $\varphi_{\mathrm{m}}$ is $0.10 \mathrm{~mol} \mathrm{O}_{2} / \mathrm{mol}$ photons (Senger 1982). The maximum quantum efficiency does not appear to depend on the light level to which a species is acclimated (Senger \& Fleischhacker 1978, Ley \& Mauzerall 1982, Geider et al. 1985), and there is little evidence to suggest interspecific variations. For these reasons we will consider $\varphi_{\mathrm{m}}$ to be constant, although we recognize that the magnitude of $\varphi_{m}$ is still contentious (Pirt 1983). Implicit in Eq. 11 is a photosynthetic quotient of unity.

\section{Light-saturated, carbon-specific photosynthesis rate $\left(P_{m}^{c}\right)$}

There are relatively few observations of the dependence of $P_{\mathrm{m}}^{c}$ on the light level to which cells have been acclimated. Mass-specific and carbon-specific, lightsaturated photosynthesis rates show less than 2-fold variations over a wide range of PFDs in nutrient-sufficient cultures of several species of microalgae (Myers 1970. Prézelin 1976, Foy \& Gibson 1982, Vincent 1982, Chang et al. 1983, Raps et al. 1983, Geider 1984, Geider et al. 1985). For this discussion we assume that $\mathrm{P}_{\mathrm{m}}^{\mathrm{c}}$ is a species-specific constant. This is similar to the approach taken by Steele (1962) in an interesting discussion of environmental control of photosynthesis and the chlorophylla:carbon ratio in the sea. There is insufficient data to evaluate the size dependence of $P_{m}^{c}$. 


\section{Chlorophyll a: carbon ratio $(\vartheta)$}

The chlorophyll a:carbon ratio of microalgae can vary by an order of magnitude from under 0.01 to over $0.1 \mathrm{~g} \mathrm{chla/g} \mathrm{C}$ depending on environmental conditions. In nutrient-sufficient cultures this ratio decreases with increasing PFD for 4 species of diatoms under continuous illumination at 18 to $22^{\circ} \mathrm{C}$ (Fig. 1). The data

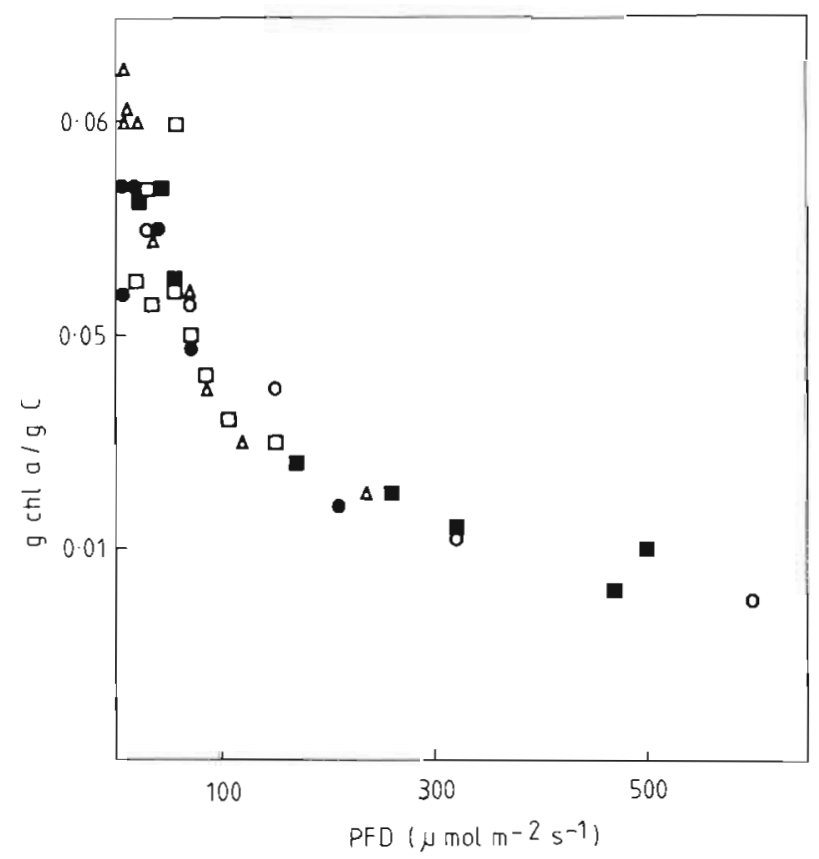

Fig. 1. Dependence of chlorophyll a: carbon ratio on photon flux density in 4 diatom species: (O) Thalassiosira weissflogui (Falkowski et al. 1985); (ㅁ) Fragillaria crotonensis (Rhee \& Gotham 1981); (ロ) Thalassiosira pseudonana (Geider 1984); (A) Phaeodactylum tricornutum (Geider et al. 1985). All observations are for cells cultured under continuous illumination at a temperature between 18 and $22^{\circ} \mathrm{C}$

suggest that there is little interspecific variability, but a pronounced PFD dependence. Comparisons of the chlorophyll a: carbon ratio in diatoms (Taguchi 1976, Durbin 1977, Blasco et al. 1982) and chlorophytes (Schlesinger \& Shuter 1981) cultured under the same environmental conditions indicate that this ratio is independent of cell size. Consistent with this conclusion are observations that cell chlorophyll $a$, protein, lipid and carbohydrate contents have the same size dependence in both diatoms and dinoflagellates (Chan 1978, Hitchcock 1982). Because of the small interspecific differences of chlorophyll a:carbon within classes of microalgae, the taxonomic differences are quite evident with the ratio decreasing in the following order: chlorophytes $>$ diatoms $>$ dinoflagellates.

To provide a quantitative description of the dependence of $\theta$ on PFD we note that the carbon: chlorophyll a ratio $(1 / \theta)$ is often observed to increase linearly with PFD in nutrient-sufficient cultures. Eq. 12 follows from the linear relation of $1 / \vartheta$ and PFD.

$$
1 / \theta=1 / \theta_{0}+\varepsilon I
$$

where $\theta_{0}=$ the value of the chlorophyll $a$ :carbon ratio at $I=0 ; \varepsilon=$ the slope of the regression of $(1 / \theta)$ on $I$.

\section{Absorption cross-section $\left(\mathrm{a}_{\mathrm{chl}}\right)$}

In theory the absorption cross-section can be expressed in terms of cell geometry and the intracellular pigment content. Expression of the absorption crosssection in terms of chlorophyll a $\left(a_{c h l}\right)$ is based on the assumptions that chlorophyll $a$ is the major light-harvesting pigment and that there is a relatively constant stoichiometry of accessory pigments to chlorophyll $a$. For homogeneous, spherical cells MIE theory can be used to derive an equation for $\mathrm{a}_{\mathrm{chl}}$ as a function of $\theta$ and cell diameter (following Morel \& Bricaud [1981] to which the reader is directed for a derivation):

$$
a_{\mathrm{chl}}=\left(\mathrm{a}_{\mathrm{chl}}^{\mathrm{s}} / \varrho\right)(3 / 2) \mathrm{Q}(\varrho)
$$

where $\mathrm{a}_{\mathrm{chl}}=$ the whole cell, chlorophyll $a$-specific absorption cross-section $\left(\mathrm{m}^{2} / \mathrm{mg}\right.$ chla); $\mathrm{a}_{\mathrm{chl}}^{\mathrm{s}}=$ the cross-section for photosynthetic pigments in solution $\left(\mathrm{m}^{2} / \mathrm{mg}\right.$ chla $) ; \varrho=$ a dimensionless parameter defined as follows:

$$
\varrho=d C \theta a^{5} \text { chi }
$$

where $\mathrm{d}=$ cell diameter $(\mathrm{m}) ; \mathrm{C}=$ the intracellular carbon content $\left(\mathrm{mgC} \mathrm{m}^{-3}\right) ; \theta=$ the chlorophyll $a$ : carbon ratio ( $\mathrm{g}$ chla/g $\mathrm{C}$ ). The dimensionless efficiency, $Q(\varrho)$ is:

$\mathrm{Q}(\varrho)=1+2\left\{[\exp (\varrho) / \varrho]+[\exp (\varrho)-1] / \varrho^{2}\right\}$

Fig. 2 illustrates the dependence of $\mathrm{a}_{\mathrm{chl}}$ on $\varrho$ for $435 \mathrm{~nm}$ blue light. Because of the dependence of $\theta$ on PFD in nutrient-sufficient cultures (Fig. 1), the value of $\mathrm{a}_{\mathrm{chl}}$ is expected to decrease with increases in PFD; however the magnitude of this increase will depend on cell diameter. The effects of $\theta$ on $a_{\mathrm{chl}}$ for cells of different sizes is illustrated in Fig. 3. The absorption cross-section $\left(a_{\mathrm{chl}}\right)$ is less dependent on $\theta$ in small cells than in large cells.

MIE theory provides a quantitative description of the effects of cell size and pigment content on $a_{c h l}$; however, the theory is based on homogeneous distribution of pigment within the cells, an assumption which is unrealistic considering the diversity of sizes and num- 
bers of chloroplasts in microalgal cells and other cytological changes which would take place in the cyanobacteria. Observations of $a_{c h l}, \theta$, and cell carbon for Thalassiosira weissflogii, Isochrysis galbana and Procentrum micans (Falkowski et al. 1985) are consis-

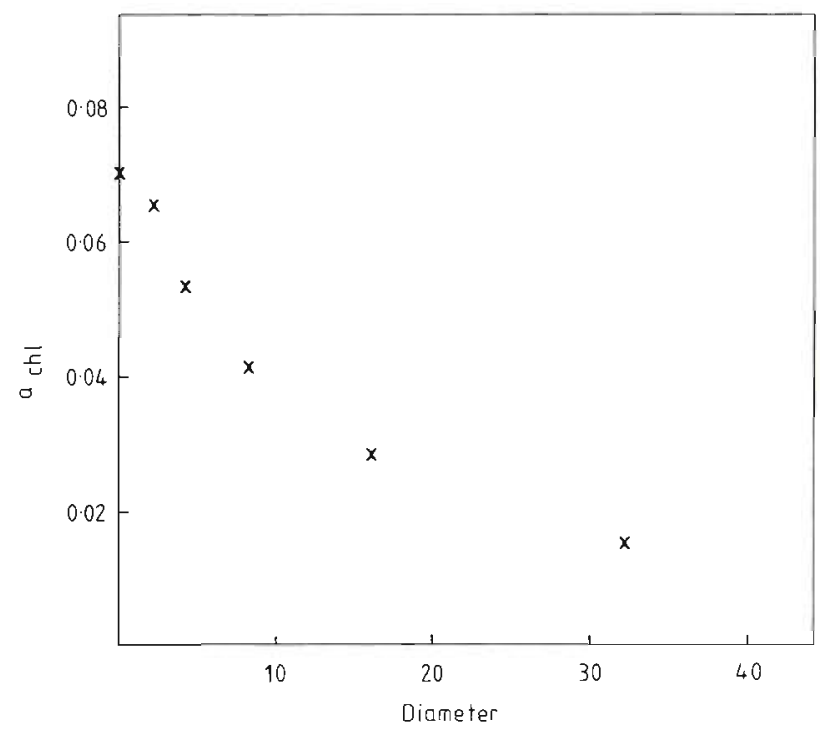

Fig. 2. Dependence of chlorophyll a-specific absorption crosssection $(435 \mathrm{~nm})$ on cell diameter as predicted by MIE theory for spherical, homogeneous cells (data from tabular summary of Morel \& Bricaud 1981). Units for $\mathrm{a}_{\mathrm{chl}}$ and cell diameter are, respectively, $\mathrm{m}^{2} / \mathrm{mg}$ chla and $\mu \mathrm{m}$

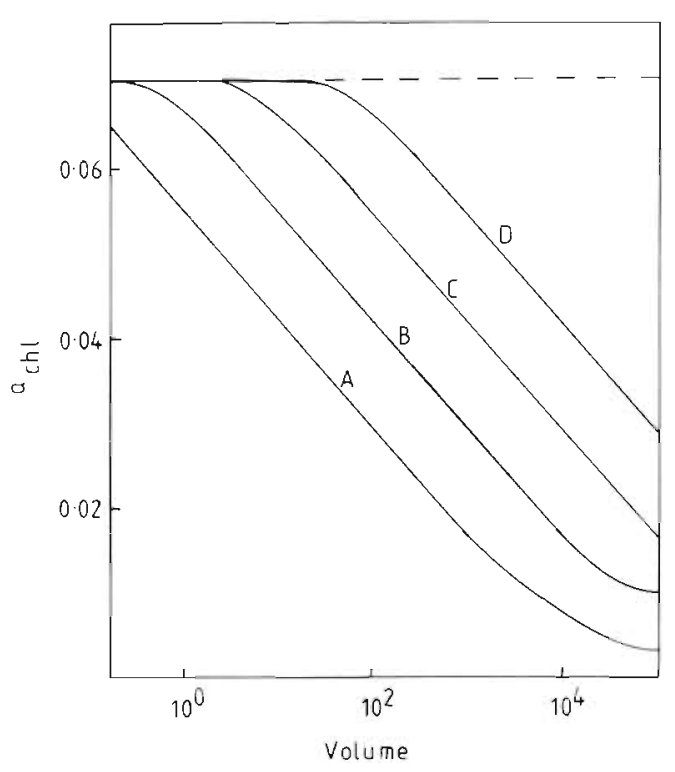

Fig. 3. Dependence of chlorophyll a-specific absorption crosssection on cell volume $\left(\mu \mathrm{m}^{3}\right)$ and chlorophyll $a$ : carbon ratio for homogeneous, spherical cells as predicted by MIE theory. Different values for the chlorophyll a:carbon ratio are indicated as follows: $\mathrm{A}, 0.067 ; \mathrm{B}, 0.033 ; \mathrm{C}, 0.017 ; \mathrm{D}, 0.0083 \mathrm{~g}$ chlorophyll a/g carbon. Note that the observations from Fig. 2 are represented by line $B$ of this figure tent with reduction of $\mathrm{a}_{\mathrm{chl}}$ in highly pigmented or large cells as illustrated in Fig. 4. In Fig. $4 \mathrm{a}_{\mathrm{chl}}$ is plotted against the product $\left(\theta \mathrm{C}^{033}\right)$ which is a measure of the dimensionless parameter $\mathrm{Q}$. The cube root of cell carbon content is used as a measure of cell diameter and the chlorophyll a: carbon ratio is a measure of intracellular pigment content.

Indirect evidence for a reduction of $\mathrm{a}_{\mathrm{chl}}$ with increases of cell size is provided by the observed reduction of the initial slope $\alpha$ ) of the PI curve (Taguchi 1976; Fig. 5) in large cells, which for a constant maximum quantum efficiency $\left(\varphi_{\mathrm{m}}\right)$ of photosynthesis implies variable $a_{c h l}$ (see Eq. 5).

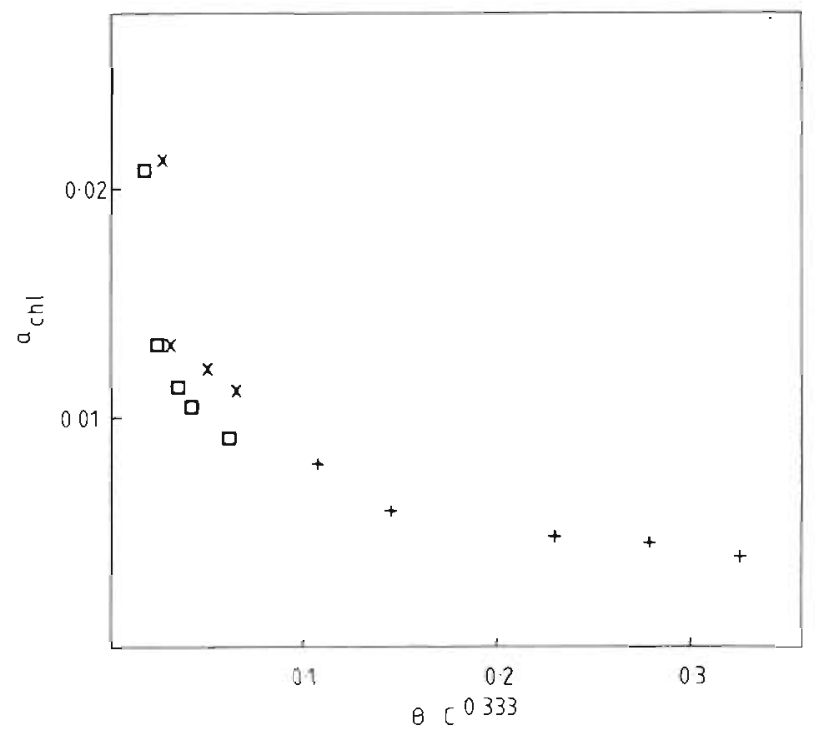

Fig. 4. Observed dependence of chlorophyll a-specific absorption cross-section on cell carbon content (C) and chlorophyll a: carbon ratio $(\theta)$ in 3 species of marine microalgae: (口) Isochrysis galbana; (+) Thalassiosira weissflogii; $(x)$ Procentrum micans; observations are from Falkowski et al. (1985). Absorption cross-section $\left(a_{c h l}\right)$ is plotted against the product $\left(\theta \mathrm{C}_{0.33}\right)$. Note the similarity of the shape of the curve to MIE theory predictions illustrated in Fig. 2

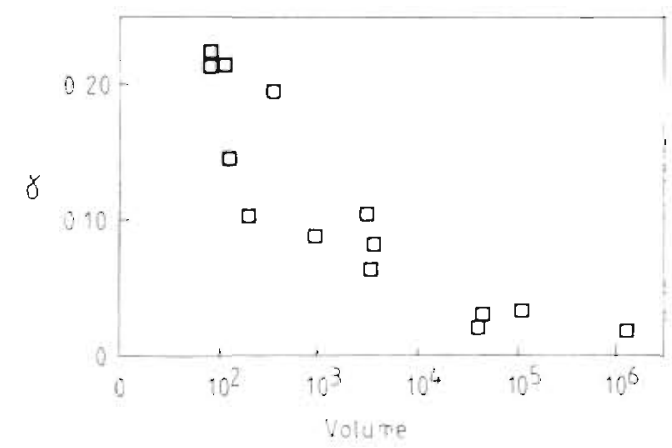

Fig. 5. Relation between initial slope of the photosynthesislight curve and cell volume in marine diatoms. Observations are from Taguchi (1976). Initial slope has units of (mg C) (mg chl a) $)^{-1} \mathrm{~h}^{-1} \mathrm{~W}^{-1} \mathrm{~m}^{2}$ and cell volume has units of $\mu \mathrm{m}^{3}$ 


\section{Light curve of growth}

Growth rate is a saturating function of PFD at low to intermediate PFDs before the onset of photoinhibition at high light levels. To describe the light curve for growth ( $\mu$-I curve) requires the specification of at least 3 parameters. These are the light-saturated maximum growth rate $\left(\mu_{m}\right)$, the compensation $\operatorname{PFD}\left(I_{c}\right)$, and a parameter that describes the PFD at which growth rate becomes light saturated $\left(I_{k}\right)$.

The maximum growth rate of diatoms ranges from about $3 \mathrm{~d}^{-1}\left(3.5 \times 10^{-5} \mathrm{~s}^{-1}\right)$ for cells of under $100 \mu \mathrm{m}^{3}$ volume to under $1 \mathrm{~d}^{-1}\left(1.1 \times 10^{-5} \mathrm{~s}^{-1}\right)$ for cells of about $10^{6} \mu^{3}$ volume at about $20^{\circ} \mathrm{C}$ (Banse $1982 \mathrm{a}$, Blasco et al. 1982). The size dependence of nutrient-sufficient maximum growth rates is well documented in the diatoms (Fig. 6) and can be described by an allometric relation:

$$
\mu_{\mathrm{m}}=\mathrm{a} \mathrm{W}^{\mathrm{b}}
$$

The slope of regressions of $\log \left(\mu_{\mathrm{m}}\right)$ on log cell mass yields an exponent which is greater than -0.25 , the expected value if metabolic rates are scaled with cell mass as in most heterotrophs (Banse 1982a); for example, Blasco et al. (1982) give a value of $b=-0.14$ for growth and $b=-0.125$ for carbon-specific ${ }^{14} \mathrm{C}$ uptake rates in diatoms.

The minimum light level which supports growth of diatoms was found by Richardson et al. (1983) to be $6.4 \pm 0.9 \mu \mathrm{mol}$ photons $\mathrm{m}^{-2} \mathrm{~s}^{-1}$ (mean \pm 1 standard error), which is probably an overestimate of the compensation PFD $\left(I_{c}\right)$ because of the limitations of the data

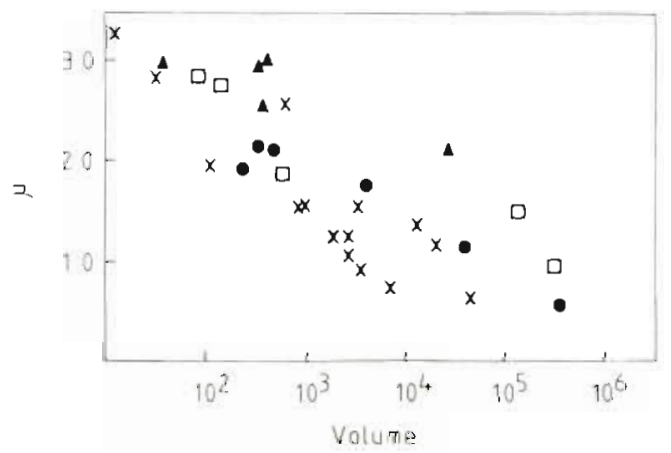

Fig. 6. Size dependence of nutrient-sufficient growth rates $(\mu)$ in diatoms. Each symbol represents a set of observations taken from a single investigation in which conditions of temperature and photon flux density were held constant; $(X)$

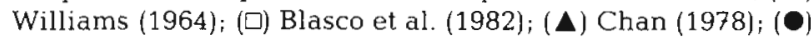
Eppley \& Sloan (1966). Excluded are observations for Cosinodiscus sp. CoA(14) from Blasco et al. which lies off the right hand margin and observations for Cosinodiscus asteromphilus and Thalassiosira fluviatilis growing at $20^{\circ} \mathrm{C}$ from Eppley \& Sloan. Growth rate is expressed in units of $d^{-1}$ and volume is expressed in units of $\mu^{3}$ base of growth measurements at low PFDs. For example, several species of diatoms for which detailed $\mu-I$ curves are available at low PFDs yield values of $I_{c}$ of under $1 \mu \mathrm{mol}$ photons $\mathrm{m}^{-2} \mathrm{~s}^{-1}$ (Thalassiosira pseudonana and Phaeodactylum tricornutum, Nelson et al. 1978; Skeletonema costatum, Falkowski \& Owens 1980). It is unfortunate that there are few observations of the light dependence of microalgal growth which extend to extremely light-limited conditions (i.e. lightlimited growth rates of under $20 \%$ of the light-saturated rate). At present there are too few observations of light-limited diatom growth to determine if there is a size dependence of the compensation PFD.

The PFD at which growth rate of diatoms becomes light saturated $\left(I_{k}\right)$ was found to be $84 \pm 8.1$ (mean \pm standard error) $\mu \mathrm{mol}$ photons $\mathrm{m}^{-2} \mathrm{~s}^{-1}$ (Richardson et al. 1983). The value of $I_{k}$ is better constrained by experimental observations than the value of $I_{c}$ because most observations of the light dependence of growth include saturating and somewhat subsaturating PFDs. Of particular interest for this discussion is the low ratio of standard error to mean which indicates little interspecific variation in the light requirements for growth within the diatoms. Where observations of the $\mu$-I curve are available for more than 1 species or clone under the same experimental conditions (Chan 1978, Nelson et al. 1978, Terry et al. 1983) plots of relative growth rate $\left(\mu / \mu_{\mathrm{m}}\right)$ against PFD show only minor differences. Although occasionally of poor resolution, these observations indicate that most species of diatoms can be characterized by the same value of $I_{k}$ independent of cell size.

\section{DISCUSSION}

Of the variables in an energy balance for microalgal growth described in the preceding section, one can tentatively conclude that the maximum quantum efficiency of photosynthesis $\left(\varphi_{\mathrm{m}}\right)$, the energy cost of synthesis ( $\xi$ ) and the chlorophyll a: carbon ratio $(\theta)$ are independent of cell size, whereas the chlorophyll aspecific absorption coefficient $\left(a_{c h l}\right)$ and the maximum growth rate $\left(\mu_{m}\right)$ decrease with increases in cell size. There is insufficient experimental evidence to evaluate the size dependence of the maintenance metabolic rate $\left(r_{m}\right)$, which in any case is a small fraction of $\mu_{m}$ and will only become a significant determinant of the growth rate at low PFDs.

The maximum growth rate can be considered as a carbon-specific catalytic activity (i.e. as the flux of carbon per unit cell carbon; [1/C] [dC/dt]), and since chlorophyll $a$ is a major photosynthetic light-harvesting pigment of diatoms, $a_{c h l}$ can be considered as a pigment-specific light-harvesting efficiency. There is a theoretical basis for a reduction of $\mathrm{a}_{\mathrm{chl}}$ with increased 
cell size because of self-shading of pigments in large cells which contain the same chlorophyll a:carbon ratio as smaller cells (Morel \& Bricaud 1981, Raven $1984 \mathrm{~b}$ ). A theoretical basis for reduction of $\mu_{\mathrm{m}}$ with increased microalgal cell size is more elusive. Large microalgae have the same basic intracellular compartmentation as small cells, so increased complexity cannot be invoked as a determinant of $\mu_{\mathrm{m}}$. In addition, it has been suggested that the proportion of cell mass invested in non-catalytic, structural material decreases with increased cell size (Shuter 1979) and so a higher $\mu_{m}$ might be anticipated in larger cells.

Banse (1982a) has recently noted that the size dependence of $\mu_{\mathrm{m}}$ in microalgae is less pronounced than in heterotrophs, and on the basis of scatter in the available observations of $\mu_{\mathrm{m}}$ and size in diatoms and dinoflagellates concluded that the size dependence of $\mu_{m}$ was undecided. In heterotrophs maximum specific growth rate (units of inverse time) scales with mass $^{-0.275}$ (Fenchel 1974) whereas recent observations of Blasco et al. (1982) indicate a mass ${ }^{-0.14}$ dependence of $\mu_{\mathrm{m}}$ for diatoms.

To derive a general expression for the light-curve of growth from a consideration of the dependence of the variables in the energy balance equation on cell size and $P F D$ will not be a simple exercise primarily because of the dependence of $\theta$ on PFD, and through $\theta$ the PFD dependence of $a_{\text {chl }}$. However, we can consider the particular cases of light-limited and light-saturated growth separately to gain some insights into the interrelations among the variables in the energy balance model (Eq. 11). At low PFDs which are within the linear region of the PI curve the energy balance reduces to the following:

$$
\mu=\left[\left(Z a_{c h l} \varphi_{m} \theta I\right)-r_{m}\right] /(1+\xi)
$$

For a constant value of $\theta$ at any particular PFD (Fig. 1), the reduction in $\mathrm{a}_{\mathrm{ch}}$ with increased cell size will result in a reduced light-limited growth rate in larger cells. Thus, the initial light-limited slope of the light curve for growth should decrease with increases in cell size. A reduction in $\mathrm{r}_{\mathrm{m}}$ with increased cell size could potentially counterbalance this effect; however, given the low observed values for $\mathrm{I}_{\mathrm{m}}$, such a reduction would be of limited extent.

There is some indirect evidence for the predicted reduction of the initial slope of the $\mu$-I curve. Observations of Williams (1964) for nutrient-sufficient growth at a light level that is likely to be non-saturating for growth yields a size dependence which is greater than the size dependence of $\mu_{\mathrm{m}}$ reported elsewhere (Banse 1982b). However, Banse (1982b) has noted limitations of the Williams (1964) data set, in particular with regard to the limited number of observations used for growth rate calculations. Observations of Schlesinger et al. (1981) indicate that the size dependence of growth rate is more pronounced at high $\left(12 \mathrm{~W} \mathrm{~m}^{-2}\right)$ than at low $\left(2 \mathrm{~W} \mathrm{~m}^{-2}\right)$ light levels, although all of these light levels are likely to be within the initial, linear portion of the light curve for growth.

Eq. 17 can be used to evaluate the compensation light level $\left(\mathrm{I}_{\mathrm{c}}\right)$ for growth by setting $\mu=0$, and solving for $I=I_{c}$ :

$$
\mathrm{I}_{\mathrm{c}}=\mathrm{r}_{\mathrm{m}} /\left(\mathrm{Z} \mathrm{a}_{\mathrm{chl}} \varphi_{\mathrm{m}} \theta\right)
$$

Given a reduction in $\mathrm{a}_{\mathrm{chl}}$ with increased cell size and assuming $r_{m}$ is independent of size, Eq. 18 indicates that $\mathrm{I}_{\mathrm{c}}$ should be larger in big cells than in small cells. To the best of our knowledge, there is no evidence available which can be used to directly test this hypothesis. In particular, there are few observations of microalgal growth at PFDs near the compensation PFD.

Under conditions in which both the photosynthesis rate and the growth rate are light-saturated the energy balance equation reduces to the following:

$$
\mathrm{P}_{\mathrm{m}}^{\mathrm{c}}=\mu_{\mathrm{m}}(1+\xi)+\mathrm{r}_{\mathrm{m}}
$$

Noting that $\mathrm{r}_{\mathrm{m}}$ will typically be less than 5 to $10 \%$ of $\mu_{m}$, Eq. 19 indicates that light-saturated, carbonspecific growth rates should be proportional to lightsaturated, maximum photosynthesis rates. To the best of our knowledge, this hypothesis is not verifiable with the available data on growth and the PI curve in microalgae.

Substituting $\mathrm{P}_{\mathrm{m}}^{\mathrm{c}}=\left[\mu_{\mathrm{m}}(1+\xi)\right]$ into the energy balance equation, neglecting $\mathrm{r}_{\mathrm{m}}$ which is small relative to $\mu$ at all but the lowest light levels, and substituting $\left[\mu^{\prime}=\mu / \mu_{\mathrm{m}}\right]$ where $\mu^{\prime}$ is the relative growth rate leads to:

$\mu^{\prime}=\mu_{m}(1+\xi)\left\{1-\exp \left[Z a_{c h l} \oiiint_{m} \theta I\right] /\left[\mu_{m}(1+\xi)\right]\right\}$

The conclusion of Richardson et al. (1983) that the light curve of growth for different diatom species appears to saturate within a narrow range of PFDs constrains the relation among the variables in the exponential function of Eq. 20. In particular, it is required that the product of the variables will be independent of size. We have already noted that $\mathrm{a}_{\mathrm{chl}}$ and $\mu_{\mathrm{m}}$ are the only variables which are size dependent, $a$ conclusion based on the independent investigations reviewed in the preceding sections (Fig. $3,4 \& 5$ ). It follows from Eq. 20 and the observation that growth saturates at similar PFDs in most diatoms that $\mu_{\mathrm{m}}$ and $a_{c h l}$ have essentially the same size dependency This 
implies covariance of $a_{c h l}$ and $\mu_{m}$, and because of the suggested relation of $\mathrm{P}_{\mathrm{m}}^{\mathrm{c}}$ and $\mu_{\mathrm{m}}$ this also implies covariance of $\mathrm{a}_{\mathrm{chl}}$ and $\mathrm{P}_{\mathrm{m}}^{\mathrm{c}}$. The observed correlation of the initial slope and light-saturated rate of the PI curve in samples of natural phytoplankton (Platt \& Jassby 1976) may reflect similarities in the size dependence of these variables, although other explanations have been advanced (Harris 1978). Also consistent with this hypothesis is the observation that oceanic picoplankton $(<1 \mu \mathrm{m}$ diameter) are characterized by higher initial slopes $\left(\alpha=\varphi_{\mathrm{m}} \mathrm{a}_{\mathrm{chl}}\right)$ and light-saturated photosynthesis rates $\left(\mathrm{P}_{\mathrm{m}}^{\mathrm{chl}}\right)$ than larger $(>1 \mu \mathrm{m}$ diameter) phytoplankters (Platt et al. 1983), although possible taxonomic differences between organisms in different size fractions (Furnas 1983) should not be ignored.

The reduction of $\mu_{m}$ and $a_{c h l}$ with size implies that small cells have a distinct catalytic advantage over large cells and should outcompete large cells at both high and low light levels. Observations of nutrient uptake by natural phytoplankton populations (Friebele et al. 1978, Smith \& Kalff 1982), of kinetic parameters of nutrient uptake in unialgal cultures (Malone $1980 \mathrm{~b}$ citing Eppley et al. 1969 and Carpenter et al. 1971) and competition experiments in chemostat cultures (Turpin \& Harrison 1980) indicate that small-celled species are more efficient nutrient scavengers than large-celled algae. Finally, the sinking rate of phytoplankton generally increases with increased cell size (Smayda 1970 , Eppley 1977) reducing the residence time of largecelled species in the euphotic zone relative to smallcelled species. Based on the physiology of microalgae, at least in conditions of balanced growth, it appears that small size is distinctly advantageous.

Consistent with the physiological advantages of small cells discussed above is the observation that small-celled picoplankton account for the dominant fraction of the algal biomass and productivity in most ocean regions (Joint \& Pomroy 1983, Li et al. 1983, Takahashi \& Bienfang 1983, Takahashi \& Hori 1984). However, large phytoplankters do persist in the oligotrophic oceans (Sournia 1981) and there is no universal morphological (including size) attribute of the oceanic shade flora (Sournia 1982).

Apparently in contradiction to the observations of size dependence of $\mu_{\mathrm{m}}$ in laboratory cultures of marine diatoms are the results of a recent study of growth rates of natural phytoplankton populations which did not reveal a size dependence of the maximum observed growth rate in 16 species of centric and pennate diatoms spanning a size range of 15 to $8700 \mu^{3}$ (Furnas 1982). Changes in environmental conditions over the course of the experimental period and differences in the number of observations of $\mu$ for the various species studied may explain the failure to observe a size dependence, although Furnas' (1982) observations do raise the question of the importance of size in controlling microalgal growth rates in nature.

Exceptions to the general pattern of decreasing biomass in larger size classes include 'blooms' of large phytoplankters following stabilization of a nutrientrich water column in the spring or associated with upwelling events. Some authors have suggested that large-celled phytoplankters may be better adapted to a variable environment because of reduced 'respiration' rates (Malone $1980 \mathrm{~b}$ ) or increased capacity to store nutrients (Turpin \& Harrison 1980) which allow survival through adverse conditions.

The argument based on respiration rates may be spurious because it depends on an observed mass dependence of dark respiration rate which is often correlated with growth rate. The dark respiration rate will not necessarily be indicative of the maintenance energy requirement, but can be expected to have a value intermediate between $\mathrm{r}_{\mathrm{m}}$ and $\mu \xi$.

As noted earlier in the discussion, small phytoplankters are characterized by higher maximum rates of nutrient uptake than large cells. In a pulsed nutrient regime small cells would be expected to have greater mass-specific nutrient uptake rates during the nutrient pulse, and so meet their nutrient demands at a faster rate than large cells. This could be offset by a greater capacity for nutrient storage in large cells that would allow these cells to continue to divide between nutrient pulses. There is, however, little evidence to support the assertion of greater fractional storage capacity in large cells (Raven 1984a). Similarities in elemental composition of large and small cells argue against changes in the ratio of stored nutrient to cell carbon.

An alternative explanation of the occasional dominance of large phytoplankters can be based on a consideration of the population dynamics of microalgae and zooplanktonic herbivores (Walsh 1976). Small microalgae are typically harvested by small invertebrates with mass-specific maximum growth rates which are the same magnitude as, or even greater than, microalgal growth rates (Banse 1982a). Increases in biomass of small microalgae should be rapidly followed by increases in the biomass of the small herbivores. In contrast, large microalgae are typically harvested by large herbivores with growth rates an order of magnitude lower than the growth rate of the microalgae. This divergence of growth rates of prey (algae) and predator (copepods) has been suggested to allow development of temporally separated blooms of both large-celled phytoplankton and copepods under conditions of large additions of nutrients to the euphotic zone. Small microalgae would not be able to take advantage of these nutrient inputs if net population increase is limited by grazing of a rapidly growing microzooplankton population. This hypothesis sug- 
gests that large size provides a refuge from small predators in the microalgae, in contrast to the alternative hypothesis that small size offers a refuge from large predators in metazoan invertebrates (Brooks \& Dodson 1965, Hall et al. 1976, Banse 1982b).

Walsh and coworkers (Walsh 1976, Walsh et al. 1978) have noted that blooms of large phytoplankton occur in the temporally more variable continental shelf regions where the storm cycle of about a week duration can account for a significant amount of the variance of water motion. The storm cycle produces a large input of nutrients on a time scale which allows uncoupling of the population dynamics of copepod herbivores and large-celled phytoplankton resulting in blooms. In the central oceanic regions this peak in the variance spectrum of water motion at the $1 \mathrm{wk}$ period is missing and blooms of large-celled phytoplankton are less conspicuous. This hypothesis can only be confirmed after further investigation of the structure of planktonic food webs. Not inconsistent with this hypothesis is the observation of Landry \& Hassett (1982) that 'small, naked ciliates graze little on the dominant phytoplankton types (e. g. diatoms) in coastal areas. Perhaps their greatest impact is on bacteria and microflagellates'.

Acknowledgements. We thank Dr. B. A. Osborne for useful comments on the manuscript and Shona McKinroy for preparing the figures. RG's research in Professor J. A. Raven's laboratory is supported by S. E. R. C.

\section{LITERATURE CITED}

Bannister, T. T. (1979). Quantitative description of steady state, nutrient-saturated algal growth including adaptation. Limnol. Oceanogr. 24: 76-96

Banse, K. (1976). Rates of growth, respiration and photosynthesis of unicellular algae as related to cell size - A review. J. Phycol. 12: 135-140

Banse, K. (1982a). Cell volumes, maximal growth rates of unicellular algae and ciliates, the role of ciliates in the marine pelagial. Limnol. Oceanogr. 27: 1059-1071

Banse, K. (1982b). Mass-scaled rates of respiration and intrinsic growth in small invertebrates. Mar Ecol. Prog. Ser. 9: 281-297

Blasco, D., Packard, T. T., Garfield, P. C. (1982). Size dependence of growth rate, respiratory electron transport system activity and chemical composition in marine diatoms in the laboratory. J. Phycol. 18: 58-63

Brooks, J. L., Dodson, S. I. (1965). Predation, body size and composition of plankton. Science 150: 28-35

Cavalier-Smith, T. (1982). SkeletaI DNA and the evolution of genome-size. Ann. Rev. Biophys. Bioeng. 11: 273-302

Chan, A. T. (1978). Comparative physiological study of marine diatoms and dinoflagellates in relation to irradiance and cell size. I. Growth under continuous light. J. Phycol. 14: 396-402

Chang, S. S., Prézelin, B. B., Trench, R. K. (1983). Mechanisms of photoadaptation in three strains of the symbiotic dinoflagellate Symbiodinium microadriaticum. Mar Biol. 76 : $219-229$
Durbin, E. G. (1977). Studies on the autecology of the marine diatom Thalassiosira nordenskioeldii. II. The influence of cell size on growth rate and carbon, nitrogen, chlorophyll $a$, and silica content. J. Phycol. 13: 150-155

Eppley, R. W (1977). The growth and culture of diatoms. In: Werner, D. (ed.). The biology of diatoms. University of California Press, Berkeley, p. 24-64

Eppley, R. W., Sloan, P. R. (1966). Growth rates of marine phytoplankton: correlation with light absorption by cell chlorophyll a. Physiologia Pl. 19: 47-59

Eppley, R. W. Rogers, J. N., McCarthy, J. J. (1969). Halfsaturation constants for uptake of nitrate and ammonium by marine phytoplankton. Limnol. Oceanogr. 14: 912-920

Falkowski, P. G. (1980). Light-shade adaptation in marine phytoplankton. In: Falkowski, P. G. (ed.) Primary productivity in the sea. Plenum Press, New York, p. 99-119

Falkowski, P. G., Owens, T. G. (1980). Light-shade adaptation. Two strategies in marine phytoplankton. Pl. Physiol. 66: $592-595$

Falkowski, P. G., Dubinsky, Z., Wyman, K. (1985). Growthirradiance relationships in phytoplankton. Limnol. Oceanogr. 30. 311-321

Fenchel, T. (1974). Intrinsic rate of natural increase: the relationship with body size. Oecologia (Berl.) 14: 317-326

Foy, R. H., Gibson, C. E. (1982). Photosynthetic characteristics of planktonic blue-green algae: changes in photosynthetic capacity and pigmentation of Oscillatoria redekei van Goor under high and low light. Br. phycol. J. 17. 183-193

French, C. S., Kohn, H. I., Tang, P. S. (1934). Temperature characteristics for metabolism of Chlorella. J. gen. Physiol. 18: 193-207

Friebele, E. S., Correll, D. L., Faust, M. A. (1978). Relationship between phytoplankton cell size and the rate of orthophosphate uptake: in situ observations of an estuarine population. Mar. Biol. 45: 39-52

Furnas, M. J. (1982). Growth rates of summer nanoplankton $(<10 \mu \mathrm{m})$ populations in lower Narragansett Bay, Rhode Island, U.S.A. Mar. Biol. 70: 105-115

Furnas, M. J. (1983). Community structure, biomass and productivity of size-fractionated summer phytoplankton populations in lower Naragansett Bay, Rhode Island. J. Plankton Res. 5: 637-655

Geider, R. J. (1984). Light and nutrient effects on microalgal physiology. Ph. D. dissertation, Dalhousie University. Halifax

Geider, R. J., Osborne, B. A., Raven, J. A. (1985). Light effects on growth and photosynthesis of Phaeodactylum tricornutum. J. Phycol. 22: 609-619

Goldman, J. C. (1980). Physiological processes, nutrient availability and the concept of relative growth rate in marine phytoplankton ecology. In: Falkowski, P. G. (ed.) Primary productivity in the sea. Plenum Press, New York, p. 179-193

Hall, D. J., Threlkeld, S. T., Burns, C. W., Crawley, P. H (1976). The size-efficiency hypothesis and the size structure of zooplankton communities. Ann. Rev. Ecol. Syst. 7 . $177-208$

Harris, G. P. (1978). Photosynthesis, productivity and growth: the physiological ecology of phytoplankton. Arch. Hydrobiol. Beih. Ergeb. Limnol. 10:1-169

Hitchcock, G. L. (1982). A comparative study of the sizedependent organic composition of marine diatoms and dinoflagellates. J. Plankton Res. 4: 363-377

Jassby, A. D., Platt, T. (1976). Mathematical formulation of the relationship between photosynthesis and light for phytoplankton. Limnol. Oceanogr. 21. 540-547

Joint, I. R. Pomroy, A. J. (1983). Production of picoplankton 
and small nanoplankton in the Celtic Sea. Mar Biol. 77: $19-27$

Kiefer, D. A., Mitchell, B. G. (1983). A simple, steady state description of phytoplankton growth based on absorption cross-section and quantum efficiency. Limnol. Oceanogr 28: $770-776$

Landry, M. R., Hassett, R. P. (1982). Estimating the grazing impact of marine micro-zooplankton. Mar Biol. 67: $283-288$

Laws, E. A., Caperon, J. (1976). Carbon and nitrogen metabolism by Monochrysis lutheri: measurement of growth-ratedependent respiration rates. Mar. Biol. 36: 85-97

Laws, E. A., Wong, D. C. L. (1978). Studies of carbon and nitrogen metabolism by three marine phytoplankton species in nitrate-limited culture. J. Phycol. 14: 406-416

Laws, E. A., Redalje, D. G., Karl, D. M., Chalup, M. S. (1983). A theoretical and experimental examination of two recent models of phytoplankton growth. J. theor Biol. 105: $469-491$

Laws, E. A., Jones, D. R., Terry, K. L., Hirata, J. A. (1985). Modifications in recent models of phytoplankton growth: theoretical developments and experimental examination of predictions. J. theor. Biol. 114: 323-341

Ley, A. C., Mauzerall, D. C. (1982). Absolute absorption crosssection for photosystem II and the minimum quantum requirement for photosynthesis in Chlorella vulgaris. Biochimica biophys. Acta 680: 95-106

Li, W. K. W. (1980). Temperature adaptation in phytoplankton: cellular and photosynthetic characteristics. In: Falkowski, P. G (ed.) Primary productivity in the sea. Plenum Press, New York, p. 259-279

Li, W K. W., Subba Rao, D. V., Harrison, W. G., Smith, J. C., Cullen, J. J., Irwin, B., Platt, T. (1983). Autotrophic picoplankton in the tropical ocean. Science 219: 292-295

Malon, T. C. (1980a). Size-fractionated primary productivity of marine phytoplankton. In: Falkowski, P. G. (ed.) Primary productivity in the sea. Plenum Press, New York, p. $301-319$

Malone, T. C. (1980b). Algal size. In: Morris, I (ed.) The physiological ecology of phytoplankton. Blackwell, Oxford, p. 433-463

Morel, A., Bricaud, A. (1981). Theoretical results concerning light absorption in a discrete medium and application to specific absorption of phytoplankton. Deep Sea Res. 11: $1375-1393$

Myers, J. (1970). Genetic and adaptive physiological characteristics observed in the chlorellas. In: Proc. IBP/PP technical meeting, Trebon, Prediction and measurement of photosynthetic production. Centre for Agricultural Publishing, Wageningen, p. $447-454$

Myers, J. (1980). On the algae: thoughts about physiology and measurements of efficiency. In: Falkowski, P. G. (ed.) Primary productivity in the sea. Plenum Press, New York, p. $1-15$

Nelson, D. M., D'Elia, C. F., Guillard, R. R. L. (1978). Growth and competition of the marine diatoms Phaeodactylum tricornutum and Thalassiosira pseudonana II: Light limitation. Mar Biol. 50: 313-318

Penning de Vries, F. W. T., Brunsting, A. H. M., van Laar, $H$. M. (1974). Products, requirements and efficiency of biosynthesis: a quantitative approach. J. theor. Biol. 45: $339-377$

Peters, R. H. (1983). The ecological implications of body size. Cambridge University Press, Cambridge

Pirt, S. (1965). The maintenance energy of bacteria in growing cultures. Proc. R. Soc. B. 163: 224-231

Pirt, S. (1983). Maximum photosynthetic efficiency: a problem to be resolved. Biotechnol Bioeng. 25: 1915-1922

Platt, T., Jassby, A. (1976). The relationship between photosynthesis and light for natural assemblages of coastal phytoplankton. J. Phycol. 12: 421-430

Platt, T., Subba Rao, D. V., Irwin, B. (1983). Photosynthesis of picoplankton in the oligotrophic ocean. Nature, Lond. 300 : $702-704$

Prézelin, B. B. (1976). The role of peridinin-chlorophyll $a$ proteins in the photosynthesis light adaptation of the marine dinoflagellate Glenodium sp. Planta 130: 225-233

Raps, S., Wyman, K., Siegelman, H. W., Falkowski, P. G. (1983). Adaptation of the cyanobacterium Microcystis aeruginosa to light intensity. Pl. Physiol. 72; 829-832

Raven, J. A. (1976). Division of labour between chloroplasts and cytoplasm. In: Barber, J. (ed.) The intact chloroplast. Elsevier/North Holland Biomedical Press, Amsterdam, p $405-443$

Raven, J. A. (1984a), Energetics and transport in aquatic plants. Alan R. Liss, Inc., New York

Raven, J. A. (1984b). A cost-benefit analysis of photon absorption by photosynthetic unicells. New Phytol. 98: 593-625

Rhee, G.-Y., Gotham, I. (1981). The effect of environmental factors on phytoplankton growth: Light and the interactions of light and nitrate limitation. Limnol. Oceanogr. 26: $649-659$

Richardson, K, Beardall, J., Raven, J. A. (1983). Adaptation of unicellular algae to irradiance: an analysis of strategies. New Phytol. 93: 157-191

Schlesinger, D. A., Molot, L. A., Shuter, B. J. (1981). Specific growth rates of freshwater algae in relation to cell size and light intensity. Can. J. Fish. Aquat. Sci. 38: 1052-1058

Schlesinger, D. A., Shuter, B. J. (1981). Patterns of growth and cell composition of freshwater algae in light-limited continuous cultures. J. Phycol. 17: 250-256

Senger, H. (1982). Efficiency of light utilization and quantum requirement of microalgae. In: Mitsui, A., Black, C. C. Jr., CRC handbook of biosolar resources, Vol. 1, Part 1, Basic principles. CRC Press, p. 55-58

Senger, H., Fleischhacker, Ph. (1978). Adaptation of the photosynthetic apparatus of Scenedesmus obliquus to strong and weak light conditions. I. Differences in pigments, photosynthetic capacity, quantum yield and dark reactions. Physiologia Pl. 43: 33-42

Shuter, B. (1979). A model of physiological adaptation in unicellular algae. J. theor. Biol. 78: 519-552

Smayda, T. J. (1970). The suspension and sinking of phytoplankton in the sea. Oceanogr mar. Biol. A. Rev. 8 353-414

Smith, R. E. H., Kalff, J. (1982). Size-dependent phosphorus uptake kinetics and cell quota in phytoplankton. J. Phycol. 18: 275-284

Sournia, A. (1981). Morphological bases of competition and succession. In: Platt, T. (ed.) Physiological bases of phytoplankton ecology. Dept. of Fisheries and Oceans, Ottawa, p. $339-346$

Sournia, A. (1982). Is there a shade flora in the marine plankton? J. Plankton Res. 4: 391-399

Steele, J. H. (1962). Environmental control of photosynthesis in the sea. Limnol. Oceanogr. 7: 137-150

Strathmaan, R. R. (1967). Estimating the organic carbon content of phytoplankton from cell volume or plasma volume. Limnol. Oceanogr. 12: 411-418

Taguchi, S. (1976). Relationship between photosynthesis and cell size of marine diatoms. J. Phycol. 12: 185-189

Takahashi, M., Bienfang, P. K. (1983). Size structure of phytoplankton biomass and photosynthesis in subtropical Hawaijan waters. Mar. Biol. 76: 203-211 
Takahashi, M., Hori, T (1984). Abundance of picoplankton in the subsurface chlorophyll maximum and tropical waters. Mar. Biol. 79: 177-186

Terry, K. L., Hirata, J., Laws, E. A. (1983). Light-limited growth of two strains of the marine diatom Phaeodactylum tricornutum Bohin: chemical composition, carbon partitioning and the diel periodicity of physiological processes. J. exp. mar. Biol. Ecol. 68; 209-227

Turpin, D. H., Harrison, P. J. (1980). Cell size manipulation in natural marine, planktonic diatom communities. Can. J. Fish. Aquat. Sci. 37: 1193-1195

Van Liere, L., Mur, L. R. (1979). Growth kinetics of Oscillatoria agardii Gomont in continuous culture, limited in its growth rate by light energy suppiy. J. gen. Microbiol. 115: 153-160
Verity, P. G. (1982). Effects on temperature, irradiance and daylength on the marine diatom Leptocylindrus danicus Cleve. 4. Growth. J. exp. mar Biol. Ecol. 55; 79-91

Vincent, W. F. (1982). Autecology of an ultraplanktonic shade alga in Lake Tahoe. J. Phycol. 18: 226-232

WaIsh, J. J. (1976). Herbivory as a factor in patterns of nutrient utilization in the sea. Limnol. Oceanogr 21, 1-13

Walsh, J. J., Whitledge, T. E., Barvenik, F. W., Wirick, C. D., Howe, S. D., Esaias, W. E., Scott, T. T. (1978). Wind events and food chain dynamics within the New York Bight. Limnol. Oceanogr. 23: 659-683

Williams, R. B. (1964). Division rates of salt marsh diatoms in relation to salinity and cell size. Ecology 45: 877-880

This review was submitted to the editor; it was accepted for printing on January 27, 1986 